\title{
APPLICATION OF COATED WHEAT BRAN TO PRODUCING BARBARI BREAD WITH INCREASED NUTRITIONAL VALUE AND IMPROVED BREAD TEXTURE AND SHELF LIFE
}

\author{
J.M. MILANI* \\ Department of Food Science and Technology, Sari Agricultural Sciences and Natural Resources University. 9 Km \\ Khazar Abad Road, P.O.Box.578, Sari. Iran.
}

(Received: 30 November 2016; accepted: 12 December 2017)

\begin{abstract}
The enrichment of bread with wheat bran as a source of dietary fibre seems to be necessary for human health, because bread is the most consumed commodity in many countries. However, wheat bran has some adverse effects on the bread quality during storage. The aim of this study was to produce barbari bread with increased nutritional value and improved texture by the addition of coated wheat bran $(0.67$ and $1.34 \%$ based on flour stearic acid or $\mathrm{St}_{1,2}$ and beeswax or $\mathrm{Bw}_{1,2}$ ). Bread made from uncoated wheat bran was used as control. The least crust to crumb ratio was seen for control and $\mathrm{Bw}_{1}$. Water activity and moisture content results showed that the crumb of $\mathrm{Bw}_{1}$ and control had the better moisture retention during storage. Textural properties of samples showed that there were no significant differences in the hardness of the samples $(\mathrm{P}>0.05)$. However, the least increase in hardness during storage was observed for stearic acid coated samples. Other texture profile analysis parameters, such as cohesiveness and springiness, showed that $\mathrm{Bw}_{1}$ and $\mathrm{Bw}_{2}$ samples had no significant changes during storage. Differential scanning calorimetry (DSC) showed the least enthalpy for Bw $\mathrm{Bw}_{1}$ after baking $\left(385.21 \mathrm{~J} \mathrm{~g}^{-1}\right)$ and during storage $\left(567.62 \mathrm{~J} \mathrm{~g}^{-1}\right)$. Accordingly, results showed that beeswax, especially at $0.67 \%$ (based on flour), is the best shell material for bran coating in order to improve bread texture and shelf life.
\end{abstract}

Keywords: coated bran, texture properties, staling, barbari bread

Wheat bran is a low cost and rich source of dietary fibres (such as cellulose, hemicelluloses, lignin, pectin, and gums), minerals (e.g., calcium, iron, zinc, and so on), and other bioactive compounds such as antioxidants (MAJzooBi et al., 2013a), which are lost as a by-product during milling process. Wheat bran can be used as a natural and cheap source of dietary fibres for fortification of certain products (CURTI et al., 2013), and their positive effects of human health have been well documented. Amongst different foods, bakery products are suitable options to increase fibre in human diets, because they are the most consumed food products (MAJzoobi et al., 2013a). In Iran, barbari bread is the second most consumed bread after lavash. It is a flat bread produced from white wheat flour. The fibre content of barbari bread is low (MAJzooBi et al., 2013b).

Effects of wheat bran addition on dough and bread properties have been extensively investigated. Bran fibre absorbs significant amounts of water from surrounding ingredients and creates textural problems, such as soggy and dry patches, in foods (OnwULATA, 2007).

CURTI and co-workers (2013) investigated the effect of bran on fresh bread properties and reported that bran altered product water status at all structural levels (from molecular to macroscopic structure), reduced loaf volume, and increased crumb hardness (depending on bran composition).

Phone: +989 15581 5087; e-mail: jmilany@yahoo.com 
Furthermore, the presence of wheat bran accelerates staling of bread; bran competes to other dough constituents such as starch, protein, etc. for free water, so less water is available for starch pasting and amylopectin retrogradation rate is increased (HARTIKAINEN et al., 2014). Similarly, the negative effect of bran addition was reported in terms of decreased gas retention, dilution and physical hindrance of the gluten network (CURTI et al., 2015).

Bread production using lipid-based coatings for wheat bran can be recommend to inhibit the moisture migration in bread texture during storage and delay staling phenomena without significant technological adverse effects on bread quality. Wheat bran coating with stearic acid and beeswax can reduce the water binding properties due to their hydrophobic properties (LAKKIS, 2016). Therefore, the aim of this study was to increase the fibre content of barbari bread with minimum adverse effects on the bread quality during storage. The quality of bread samples has been evaluated by physicochemical properties, textural characteristics, and thermal analysis.

\section{Materials and methods}

\subsection{Materials}

Wheat bran with average particle size of $280 \mu \mathrm{m}$ and wheat flour with extraction rate of $87 \%$ were supplied from the local bakery shop (Sari, Mazandaran, Iran). The wheat flour and bran belonged to the same cultivar (Triticum aestivum). Active dried yeast (Razavi Yeast Co.) and iodine free table salt were purchased from local market. Stearic acid and white beeswax with high purity were purchased from Scharlau Spain (AC 09261000) and Samchun (B 1180) Korea, respectively.

\subsection{Preparation of coated wheat bran}

At first, $0.75 \mathrm{~g}$ of stearic acid and $1.50 \mathrm{~g}$ of beeswax were casted separately in containers and melted in oven at $80^{\circ} \mathrm{C}$, then $10 \mathrm{~g}$ wheat bran was added to the melted matrix and mixed well. After cooling, the coated brans were used in dough preparation immediately.

\subsection{Preparation of dough}

Initially, $100 \mathrm{~g}$ of flour with $2 \mathrm{~g}$ of yeast and $10 \mathrm{~g}$ of coated and uncoated brans for each sample were mixed well. Then, $2 \mathrm{~g}$ of salt was dissolved in $75 \mathrm{ml}$ of water, it was added to the flour mix, and stirred (Moulinex mixer) well. In this study, bran was added at the level of $11.1 \%$ flour basis (Gomez et al., 2011). The bran was added to the flour mix as uncoated bran (control) and coated bran by beeswax and stearic acid at levels of $0.67 \%$ wt. $\left(\mathrm{Bw}_{1}, \mathrm{St}_{1}\right)$ and $1.34 \%\left(\mathrm{Bw}_{2}, \mathrm{St}_{2}\right)$. The experimental plan of bread samples is shown in Table 1.

\subsection{Bread making}

Barbari bread was prepared according to MALEKI and MILANI (2013) with slight modifications. After dough fermentation for $1.5 \mathrm{~h}$ at $38^{\circ} \mathrm{C}$ and $80-90 \%$ relative humidity (first fermentation), the dough was punched and rested for $10 \mathrm{~min}$ (second fermentation), then it was sheeted to form an oval at approximately $20 \mathrm{~cm} \times 10 \mathrm{~cm}$, with a thickness of approximately $1.5 \mathrm{~cm}$. Then, one teaspoon of Roomal (a boiling mixture of $5 \mathrm{~g}$ of flour and $100 \mathrm{ml}$ of water) was spread across the bread, and three similar grooves were made along its length, mainly for joining crust to crumb and gaining a better appearance. The dough was proofed for $5 \mathrm{~min}$ 
(last fermentation) and baked for $10 \mathrm{~min}$ at $260^{\circ} \mathrm{C}$ in an oven (Mashad Baking Industry). Three loaves of each sample were produced and the loaves were kept at room temperature for 5 days. Samples were analysed fresh (day 1) and after 3 and 5 days of storage. All measurements were done in triplicate.

Table 1. Experimental design of bread samples

\begin{tabular}{llc}
\hline Sample & Coating & $\begin{array}{c}\text { Coating concentration } \\
(\% \mathrm{wt})\end{array}$ \\
\hline Control & & 0 \\
$\mathrm{Bw}_{1}$ & None & 0.67 \\
$\mathrm{Bw}_{2}$ & & 1.34 \\
$\mathrm{St}_{1}$ & Beeswax & 0.67 \\
$\mathrm{St}_{2}$ & & 1.34 \\
\hline
\end{tabular}

Number of samples: $3 ; \mathrm{Bw}_{1}$ : coated bran by $0.67 \%$ wt. beeswax; $\mathrm{Bw}_{2}$ : coated bran by $1.34 \%$ wt. beeswax; $\mathrm{St}_{1}$ : coated bran by $0.67 \%$ wt. stearic acid; $\mathrm{St}_{2}$ : coated bran by $1.34 \%$ wt. stearic acid.

\subsection{Crust to crumb ratio}

The crust to crumb ratio was determined according to MaLeKI and Milani (2013). For evaluating the crumb to crust ratio (w/w), a loaf of bread was taken and its crust (brown parts) were separated from the crumb using a razor blade.

\subsection{Moisture content and water activity}

Crumb and crust moisture contents were determined in triplicate for each sample at 1,3, and 5 days of storage by weight loss at $105^{\circ} \mathrm{C}$ to constant weight, according to the method used by CURTI and co-workers (2013). The water activity of the crumb and crust was measured at $25^{\circ} \mathrm{C}$ by a Labswift-a $\mathrm{w}_{\mathrm{w}}$ (Novasina, Switzerland).

\subsection{Crumb texture}

Crumb texture analysis was performed according to GoMEZ and co-workers (2011) using a TA-CT3 (Brookfield-CT3). Accordingly, textural measurements were performed on $20 \mathrm{~mm}$ thick slices of barbari bread. A $25-\mathrm{mm}$ diameter cylindrical probe was used for textural profile analysis (TPA) with double compression test to penetrate to a depth of $50 \%$ with a speed of $1 \mathrm{~mm} \mathrm{~s}^{-1}$ and with a $30 \mathrm{~s}$ delay between first and second compressions. Hardness, cohesiveness, chewiness, springiness, and resilience were calculated from the TPA graph. The measurements were repeated at 1,3 , and 5 days of storage.

\subsection{Thermal analysis}

Differential scanning calorimetry (DSC) was used to evaluate the starch retrogradation according to RiвоTTA and BAIL (2007) with slight modifications. Calorimetric measurements were performed with a Pyris 6 DSC (Perkin Elmer, USA). A sample (approximately $10 \mathrm{mg}$ ) from fresh and stored bread samples was placed in an aluminium pan and tightly packed. The pan was closed with a cap, it was weighed and heated at $10^{\circ} \mathrm{C} \mathrm{min}-1$ from 10 to $150{ }^{\circ} \mathrm{C}$. The analysis was repeated at 1,3 , and 5 days of storage. 


\subsection{Statistical analysis}

In order to analyse the statistical data, analysis of variance (ANOVA) was used in SAS version 9.2 software (SAS Institute, Inc., Cary, North Carolina). The significant differences $(\mathrm{P}<0.05)$ between means were determined by Duncan test and final values were recorded as mean \pm standard deviation (SD).

\section{Results and discussion}

\subsection{Crust to crumb ratio}

The crust to crumb ratio was studied as an important quality factor in baking technology. The results of the crust to crumb ratio are shown in Table 2. The lowest value for crust to crumb ratio was reported for control $(0.113 \pm 0.02)$ and $\mathrm{B}_{\mathrm{w}_{1}}(0.114 \pm 0.01)$. Thicker crust causes more migration of moisture from crumb to crust (MALEKI \& MiLANI, 2013). The reason for thinner crust formation might be water absorption by bran constituents and so, lack of water in the crust during baking. Accordingly, $\mathrm{Bw}_{1}$ sample had better water holding capacity due to bran particles, and after melting in the oven, the bran is able to absorb more water evaporates. Thus, less water is available in crust for the browning reactions, consequently the crust formation is diminished.

Table 2. Crumb to crust ratio, moisture content, and water activity of crumb and crust of samples during storage

\begin{tabular}{|c|c|c|c|c|c|c|}
\hline \multirow[t]{2}{*}{ Sample } & \multirow[t]{2}{*}{ Day } & \multirow[t]{2}{*}{ Crust/crumb } & \multicolumn{2}{|c|}{ Water activity } & \multicolumn{2}{|c|}{ Moisture content (\%) } \\
\hline & & & Crumb & Crust & Crumb & Crust \\
\hline \multirow[t]{3}{*}{ Control } & 1 & $0.113 \pm 0.02^{\mathrm{a}}$ & $0.958 \pm 0.0^{\mathrm{a}}$ & $0.892 \pm 0.0^{\mathrm{a}}$ & $44.81 \pm 0.9^{\mathrm{a}}$ & $18.01 \pm 0.5^{\mathrm{a}}$ \\
\hline & 3 & & $0.956 \pm 0.0^{\mathrm{ab}}$ & $0.932 \pm 0.0^{\mathrm{c}}$ & $35.61 \pm 0.4^{\mathrm{a}}$ & $28 \pm 0.4^{\mathrm{b}}$ \\
\hline & 5 & & $0.955 \pm 0.0^{\mathrm{a}}$ & $0.935 \pm 0.0^{\mathrm{c}}$ & $35.28 \pm 0.5^{\mathrm{a}}$ & $28.21 \pm 0.1^{\mathrm{c}}$ \\
\hline \multirow[t]{3}{*}{$\mathrm{Bw}_{1}$} & 1 & $0.114 \pm 0.01^{\mathrm{a}}$ & $0.959 \pm 0.0^{\mathrm{a}}$ & $0.889 \pm 0.0^{\mathrm{a}}$ & $44.76 \pm 0.1^{\mathrm{a}}$ & $17.77 \pm 0.2^{\mathrm{a}}$ \\
\hline & 3 & & $0.958 \pm 0.0^{\mathrm{a}}$ & $0.933 \pm 0.0^{\mathrm{bc}}$ & $34.24 \pm 0.2^{\mathrm{b}}$ & $27.86 \pm 0.3^{\mathrm{b}}$ \\
\hline & 5 & & $0.957 \pm 0.0^{\mathrm{a}}$ & $0.936 \pm 0.0^{\mathrm{bc}}$ & $33.86 \pm 0.1^{\mathrm{b}}$ & $28.24 \pm 0.2^{\mathrm{c}}$ \\
\hline \multirow[t]{3}{*}{$\mathrm{Bw}_{2}$} & 1 & $0.128 \pm 0.2^{\mathrm{b}}$ & $0.963 \pm 0.0^{\mathrm{a}}$ & $0.887 \pm 0.0^{\mathrm{a}}$ & $44.77 \pm 0.1^{\mathrm{a}}$ & $17.66 \pm 0.6^{\mathrm{a}}$ \\
\hline & 3 & & $0.948 \pm 0.0^{\mathrm{c}}$ & $0.941 \pm 0.0^{\mathrm{a}}$ & $33.27 \pm 0.4^{\mathrm{c}}$ & $28.54 \pm 0.1^{\mathrm{ab}}$ \\
\hline & 5 & & $0.946 \pm 0.0^{\mathrm{b}}$ & $0.944 \pm 0.0^{\mathrm{a}}$ & $32.43 \pm 0.4^{\mathrm{dc}}$ & $29.35 \pm 0.2^{\mathrm{b}}$ \\
\hline \multirow[t]{3}{*}{$\mathrm{St}_{1}$} & 1 & $0.126 \pm 0.1^{\mathrm{ab}}$ & $0.961 \pm 0.0^{\mathrm{a}}$ & $0.897 \pm 0.0^{\mathrm{a}}$ & $44.55 \pm 0.4^{\mathrm{a}}$ & $17.89 \pm 0.1^{\mathrm{a}}$ \\
\hline & 3 & & $0.951 \pm 0.0^{\mathrm{bc}}$ & $0.94 \pm 0.0^{\mathrm{ab}}$ & $31.18 \pm 0.6^{\mathrm{c}}$ & $28.59 \pm 0.5^{\mathrm{ab}}$ \\
\hline & 5 & & $0.947 \pm 0.0^{\mathrm{b}}$ & $0.941 \pm 0.0^{\mathrm{ab}}$ & $32.9 \pm 0.1^{\mathrm{c}}$ & $29.22 \pm 0.5^{\mathrm{b}}$ \\
\hline \multirow[t]{3}{*}{$\mathrm{St}_{2}$} & 1 & $0.139 \pm 0.2^{\mathrm{b}}$ & $0.964 \pm 0.0^{\mathrm{a}}$ & $0.89 \pm 0.0^{\mathrm{a}}$ & $44.50 \pm 0.4^{\mathrm{a}}$ & $18.02 \pm 0.2^{\mathrm{a}}$ \\
\hline & 3 & & $0.949 \pm 0.0^{\mathrm{c}}$ & $0.942 \pm 0.0^{\mathrm{a}}$ & $32.99 \pm 0.1^{\mathrm{c}}$ & $28.84 \pm 0.4^{\mathrm{a}}$ \\
\hline & 5 & & $0.945 \pm 0.0^{\mathrm{b}}$ & $0.944 \pm 0.0^{\mathrm{a}}$ & $31.79 \pm 0.3^{\mathrm{d}}$ & $30.15 \pm 0.2^{\mathrm{a}}$ \\
\hline
\end{tabular}

*: Values are reported as mean $\pm \mathrm{SD}$ of three replications.

a-d : Each column with the same code letters are not significantly different at $\mathrm{P}<0.05$.

$\mathrm{Bw}_{1}$ : coated bran by $0.67 \%$ wt. beeswax; $\mathrm{Bw}_{2}$ : coated bran by $1.34 \%$ wt. beeswax; $\mathrm{St}_{1}$ : coated bran by $0.67 \%$ wt. stearic acid; $\mathrm{St}_{2}$ : coated bran by $1.34 \%$ wt. stearic acid. 


\subsection{Moisture content and water activity}

The moisture contents of crumb and crust of samples during storage are shown in Table 2. There was no significant difference between crust and crumb moisture content for fresh bread samples. However, crumb moisture content decreased during storage time. On the third and fifth days, maximum moisture content of crumb was related to control. PURHAGEN and coworkers (2011) observed that bread containing wheat bran maintains more moisture during storage. Next to control, $\mathrm{Bw}_{1}$ sample had the highest crumb moisture content during storage, which shows its better performance for absorbing water evaporates. According to the results, thinner crust of bread causes less migration of moisture from crumb to crust. The lowest crumb moisture content on the third day was related to $\mathrm{St}_{1}, \mathrm{St}_{2}$, and $\mathrm{Bw}_{2}$, and the lowest crumb moisture content on the fifth day was related to $\mathrm{St}_{2}$. $\mathrm{St}_{2}$ sample had the highest crust moisture content during storage.

The results of water activity are shown in Table 2 . There was no significant difference between crust and crumb water activity for fresh bread samples. On the third day, the highest water activity for crumb was related to $\mathrm{Bw}_{1}$. On the fifth day, the control and $\mathrm{Bw}_{1}$ had the highest crumb water activity. The lowest water activity of the crust was related to control and $\mathrm{Bw}_{1}$ during storage. According to LEBESI and TZIA (2011), in spite of an increase of moisture content with incorporation of dietary fibre, water activity of the samples was not changed. These results are likely indicative of better water absorption by bran and preventing water migration to crust. The coating of wheat bran creates a film around it and reduces water absorption of bran, thus it causes better starch gelatinization and gluten network formation.

\subsection{Crumb texture}

The results of bread texture analysis (Table 3 ) showed that there was no significant difference between hardness of fresh bread samples. With increasing storage time, hardness of samples increased, and the highest increase was observed in the control sample. On the third day of storage, the highest hardness of the crumb was related to control and $\mathrm{Bw}_{1}$ samples and on the fifth day of storage, it was related to control sample. In fresh bread samples, the highest cohesiveness belonged to control and $\mathrm{Bw}_{1}$, and the lowest cohesiveness belonged to $\mathrm{St}_{2}$. During storage the cohesiveness decreased in all samples. On the third and fifth days, $\mathrm{Bw}_{1}$ had the highest cohesiveness. In terms of springiness and resilience, the control, $\mathrm{Bw}_{1}$, and $\mathrm{Bw}_{2}$ had the highest springiness and resilience in fresh and stored bread samples as well. On the third and fifth days, $\mathrm{St}_{2}$ had the lowest cohesiveness, springiness, and resilience. On any day of storage, control sample showed more chewiness than other samples.

Although hardness is the most important factor for evaluation of bread staling, MAJzooBI and co-workers (2014) reported that bran hydrocolloids absorb water, decrease lubricating effects of water, and thus increase hardness. It seems that increase of crumb hardness in control and $\mathrm{B}_{\mathrm{W} 1}$ is related to water absorption properties of bran and decrease of lubricating effects of water, resulting in great cohesiveness and springiness of these samples during storage. RAPHAELIDES and GEORGIADIS (2006) described swelling of retarded granules in presence of fatty acids. STAMPfli and NERDEN (1995) reported that gelatinized granules increased bread hardness during storage. The less gelatinized granules can be the reason of less hardness in bread samples containing coated bran with stearic acid during storage. 
Table 3. Crumb texture profile analyses of bread samples during storage

\begin{tabular}{lcccccc}
\hline Sample & Day & Hardness $(\mathrm{g})$ & Cohesiveness & Chewiness $(\mathrm{g})$ & Springiness & Resilience \\
\hline \multirow{3}{*}{ Control } & 1 & $1121 \pm 0.0^{\mathrm{a}}$ & $0.69 \pm 0.0^{\mathrm{a}}$ & $70.63 \pm 0.0^{\mathrm{a}}$ & $9.28 \pm 0.0^{\mathrm{a}}$ & $0.36 \pm 0.0^{\mathrm{a}}$ \\
& 3 & $2927 \pm 0.1^{\mathrm{a}}$ & $0.44 \pm 0.0^{\mathrm{b}}$ & $113.70 \pm 0.1^{\mathrm{a}}$ & $8.98 \pm 0.2^{\mathrm{a}}$ & $0.21 \pm 0.0^{\mathrm{a}}$ \\
& 5 & $7451 \pm 0.0^{\mathrm{a}}$ & $0.3 \pm 0.0^{\mathrm{ab}}$ & $233.63 \pm 0.0^{\mathrm{a}}$ & $10.59 \pm 0.3^{\mathrm{a}}$ & $0.13 \pm 0.0^{\mathrm{a}}$ \\
& 1 & $986 \pm 0.1^{\mathrm{a}}$ & $0.69 \pm 0.0^{\mathrm{a}}$ & $61.70 \pm 0.1^{\mathrm{ab}}$ & $9.21 \pm 0.03^{\mathrm{a}}$ & $0.34 \pm 0.0^{\mathrm{b}}$ \\
$\mathrm{Bw}_{1}$ & 3 & $2844 \pm 0.1^{\mathrm{a}}$ & $0.47 \pm 0.0^{\mathrm{a}}$ & $119.17 \pm 0.1^{\mathrm{a}}$ & $8.96 \pm 0.2^{\mathrm{a}}$ & $0.23 \pm 0.0^{\mathrm{a}}$ \\
& 5 & $6431 \pm 0.0^{\mathrm{bc}}$ & $0.306 \pm 0.0^{\mathrm{a}}$ & $204.2 \pm 0.0^{\mathrm{b}}$ & $10.61 \pm 0.1^{\mathrm{a}}$ & $0.12 \pm 0.0^{\mathrm{a}}$ \\
& 1 & $982 \pm 0.0^{\mathrm{a}}$ & $0.66 \pm 0.0^{\mathrm{b}}$ & $58.10 \pm 0.0^{\mathrm{ab}}$ & $9.03 \pm 0.1^{\mathrm{a}}$ & $0.33 \pm 0.0^{\mathrm{b}}$ \\
$\mathrm{Bw}_{2}$ & 3 & $2541 \pm 0.1^{\mathrm{ab}}$ & $0.43 \pm 0.0^{\mathrm{b}}$ & $59.03 \pm 0.5^{\mathrm{b}}$ & $8.60 \pm .07^{\mathrm{ab}}$ & $0.20 \pm 0.0^{\mathrm{ab}}$ \\
& 5 & $6754 \pm 0.0^{\mathrm{b}}$ & $0.29 \pm 0.0^{\mathrm{c}}$ & $200.87 \pm 0.0^{\mathrm{b}}$ & $10.40 \pm 0.1^{\mathrm{a}}$ & $0.12 \pm 0.0^{\mathrm{a}}$ \\
& 1 & $1085 \pm 0.1^{\mathrm{a}}$ & $0.60 \pm 0.0^{\mathrm{c}}$ & $54.13 \pm 0.1^{\mathrm{bc}}$ & $8.40 \pm 0.3^{\mathrm{b}}$ & $0.23 \pm 0.0^{\mathrm{c}}$ \\
$\mathrm{St}_{1}$ & 3 & $1614 \pm 0.1^{\mathrm{b}}$ & $0.42 \pm 0.0^{\mathrm{b}}$ & $59.93 \pm 0.1^{\mathrm{b}}$ & $8.35 \pm 0.1^{\mathrm{bc}}$ & $0.17 \pm 0.0^{\mathrm{bc}}$ \\
& 5 & $5119 \pm 0.0^{\mathrm{d}}$ & $0.29 \pm 0.0^{\mathrm{bc}}$ & $147.9 \pm 0.0^{\mathrm{c}}$ & $10.2 \pm 0.4^{\mathrm{b}}$ & $0.10 \pm 0.0^{\mathrm{b}}$ \\
& 1 & $1174 \pm 0.1^{\mathrm{a}}$ & $0.51 \pm 0.0^{\mathrm{d}}$ & $41.16 \pm 0.1^{\mathrm{c}}$ & $7.04 \pm 0.6^{\mathrm{c}}$ & $0.18 \pm 0.0^{\mathrm{d}}$ \\
$\mathrm{St}_{2}$ & 3 & $1765 \pm 0.1^{\mathrm{b}}$ & $0.43 \pm 0.0^{\mathrm{b}}$ & $60.57 \pm 0.1^{\mathrm{b}}$ & $8.12 \pm 0.4^{\mathrm{c}}$ & $0.16 \pm 0.0^{\mathrm{c}}$ \\
& 5 & $5819 \pm 0.0^{\mathrm{c}}$ & $0.28 \pm 0.0^{\mathrm{c}}$ & $148.83 \pm 0.1^{\mathrm{c}}$ & $9.17 \pm 0.1^{\mathrm{c}}$ & $0.09 \pm 0.0^{\mathrm{b}}$ \\
\hline
\end{tabular}

*: Values are reported as mean $\pm \mathrm{SD}$ of three replications.

${ }^{\mathrm{a}-\mathrm{d}}$ Each column with the same code letters are not significantly different at $\mathrm{P}<0.05$.

$\mathrm{Bw}_{1}$ : coated bran by $0.67 \%$ wt. beeswax; $\mathrm{Bw}_{2}$ : coated bran by $1.34 \%$ wt. beeswax; $\mathrm{St}_{1}$ : coated bran by $0.67 \%$ wt. stearic acid; $\mathrm{St}_{2}$ : coated bran by $1.34 \%$ wt. stearic acid.

CAI and co-workers (2014) reported that bread samples with less cohesiveness become staler than bread samples with high cohesiveness during storage. In this study, bread samples containing coated bran with stearic acid had the lowest hardness. Also, the lowest cohesiveness, springiness, and resilience were observed for these samples during storage. ANGIOLONI and COLLAR (2011) reported that lipids are connected to proteins during dough mixing and bound to starch during baking stage. In presence of higher fibre content, it seems that lipid-protein and lipid-starch linkages are reduced due to interaction between fibres and endogenous biopolymers. It can be the reason of less springiness of these samples, despite the presence of fatty acids in fresh $\mathrm{St}_{1}$ and $\mathrm{St}_{2}$ samples. Reduction of springiness and resilience of bread crumb can be representative of staling in bread during storage (CAUvaIN, 2004). Reducing springiness in bread samples containing coated bran with stearic acid probably relates to loss of water during storage. In $\mathrm{B}_{\mathrm{w}_{2}}$, despite the reduction of moisture content, springiness was great, meaning that it is probably related to the viscoelastic properties of beeswax (Shellhammer et al., 1997).

\subsection{Thermal analysis}

Results of thermal analysis of bread samples during storage are shown in Table 4. The enthalpy $(\Delta \mathrm{H})$ of all samples significantly increased during storage. The highest $\Delta \mathrm{H}$ was related to control and the lowest $\Delta \mathrm{H}$ was seen in fresh $\mathrm{St}_{2}$ sample. 
Table 4. Enthalpy changes $\left(\mathrm{J} \mathrm{g}^{-1}\right)$ of starch retrogradation during bread storage

\begin{tabular}{lccccc}
\hline Day & Control & $\mathrm{Bw}_{1}$ & $\mathrm{Bw}_{2}$ & $\mathrm{St}_{1}$ & $\mathrm{St}_{2}$ \\
\hline 1 & 405 & 385 & 412 & 486 & 385 \\
3 & 597 & 449 & 458 & 642 & 507 \\
5 & 629 & 567 & 547 & 641 & 722 \\
\hline
\end{tabular}

The highest $\Delta \mathrm{H}$ belonged to $\mathrm{St}_{1}$ sample on the third day and $\mathrm{St}_{2}$ sample on the fifth day. These results showed that stearic acid coatings were unable to delay staling in comparison with control, but beeswax coatings were suitable for this purpose. GAY and BEMILLER (2003) reported that losing of moisture is not the main reason for staling, but it can accelerate reactions that lead to staling. Moisture migration in bread samples containing coated bran with stearic acid is one of the reasons for increased staling. The lowest $\Delta \mathrm{H}$ was observed during storage in bread samples containing coated bran with beeswax, due to emulsifying properties of beeswax (HAN et al., 2006). Starch-emulsifier interactions postpone the retrogradation of starch, this effect is explained by prevention of side-by-side stacking of starch helix, thus reduced nucleation sites for retrogradation (HASENHUETTL \& HARTEL, 2008). Although migration of moisture in $\mathrm{B}_{\mathrm{w}_{2}}$ sample is high, it seems that moisture level changes have no effect on staling of this sample during storage, and the emulsifying property of beeswax has been effective in retarding staling.

\section{Conclusions}

The addition of coated bran significantly affected bread staling. The coating of wheat bran created a film and reduced water absorption of bran, allowing better starch gelatinization and formation of gluten network. The coating of wheat bran by beeswax, that has emulsifying and hydrophobic properties, could be effective in formation of gluten network and starch gelatinization. Also, the least increase in enthalpy of amylopectin retrogradation belonged to bread samples containing coated bran with beeswax. The results of this research showed that beeswax at $0.67 \%$ (based on flour) had the best texture properties and most moisture content during storage. Our work showed that coating reduced undesirable effects of added bran to bread formulation. Sensory evaluation showed that bran coated using beeswax had the highest scores in terms of porosity, chewing ability, flavour, and overall score, but stearic acid coated sample showed the least hardness (HosseinI \& MiLANI, 2016). Therefore, beeswax can be used for retarding staling problem in various types of bread and cakes as well as improving the nutritional value of bread, especially dietary fibre content. The coated bran cannot compete other dough constituents regarding water absorption in dough, so more water remains available for starch and protein, instead it can hold more moisture in bread after coating materials melt during storage. We recommend that further methods be studied for bran coating using beeswax as shell material to optimize coating method for industrial purposes. 


\section{References}

Angioloni, A. \& Collar, C. (2011): Significance of lipid binding on the functional and nutritional profiles of single and multigrain matrices. Eur. Food Res. Technol., 233, 141-150.

CAI, L., Chol, I., Hyun, J.N., JeOng, Y.K. \& BAiK, B.K. (2014): Influence of bran particle size on bread-baking quality of whole gain wheat flour and starch retrogradation. Cereal Chem., 91, 65-71.

Cauvain, S.P. (2004): Improving the texture of bread. -in: Kilcast, D. (Ed.) Texture in food, Volume 2. Solid Foods. Woodhead Publishing Limited, Abington Hall. 537 pages.

Curti, E., Carini, E., Bonacini, G., Tribuzio, G. \& Vittadini, E. (2013): Effect of the addition of bran fractions on bread properties. J. Cereal Sci., 57, 325-332.

Curti, E., Carini, E., Tribuzio, G. \& Vittadini, E. (2015): Effect of bran on bread staling: physico-chemical characterization and molecular mobility. J. Cereal Sci., 65, 25-30.

Gay, J.A. \& Bemiller, J.N. (2003): Bread staling: Molecular basis and control. Compr. Rev. Food Sci. F., 2, 1-22.

Gomez, M., Jimenez, S., Ruiz, E. \& Oliete, B. (2011): Effect of extruded wheat bran on dough rheology and bread quality. LWT - Food Sci. Technol., 44, 2231-2237.

Han, J.H., Seo, G.H., PARK, I.M., Kim, G.N. \& Lee, D.S. (2006): Physical and mechanical properties of pea starch edible films containing beeswax emulsions. J. Food Sci., 71, E290-E296.

Hartikainen, K., Poutanen, K. \& Katina, K. (2014): Influence of bioprocessed wheat bran on the physical and chemical properties of dough and on wheat bread texture. Cereal Chem., 91, 115-123.

Hasenhuettl, G.L. \& Hartel, R.W. (2008): Food emulsifiers and their applications. 2nd ed., Springer, New York. 426 pages.

Hosseini, A. \& Milani, J.M. (2016): Effect of coated bran on the physical properties of barbari bread. AFS Adv. Food Sci., 38, 70-75.

LAKKIS, J.M. (2016): Encapsulation and controlled release in bakery applications. -in: LAKKIS, J.M. (2016) Encapsulation and controlled release technologies in food systems. $2^{\text {nd }}$ ed., John Wiley \& Sons. 408 pages.

LeBEsI, D.M. \& TzIA, C. (2011): Effect of the addition of different dietary fiber and edible cereal bran sources on the baking and sensory characteristics of cupcakes. Food Bioprocess. Tech., 4, 710-722.

Majzoobi, M., Pashangah, S. \& Narahnaky, A. (2013a): Effect of different particle sizes and levels of wheat bran on the physical and nutritional quality of sponge cake. Int. J. Food Eng., 9, 1-9.

Majzoobi, M., Farahnaky, A., Nematolahi, Z., Mohammadi Hashemi, M. \& Taghipour Ardakani, J.M. (2013b): Effect of different levels and particle sizes of wheat bran on the quality of flat bread. J. Agr. Sci. Tech .-Iran, $15,115-123$

Majzoobi, M., Pashangeh, S., Aminlari, L. \& Farahnaky, A. (2014): Modeling the effects of the quantity and particle size of wheat bran on some properties of bread dough using response surface methodology. Int. J. Food Eng., 10, 511-519.

MaleKi, G. \& Milani, J. (2013): Effect of guar gum, xanthan gum, cmc and hpmc on dough rheology and physical properties of barbari bread. Food Sci. Technol. Res., 19, 353-358.

Onwulata, Ch.I. (2007): Baking properties of milk protein-coated wheat bran. J. Food Process. Pres., 32, $24-38$.

Purhagen, J.K., Sjoo, M.E. \& Eliasson, A.C. (2011): Fiber rich additives; the effect on staling and their function in free-standing and pan-baked bread. J. Sci. Food Agr., 92, 1201-1213.

Raphaelides, S.N. \& Georgiadis, N. (2006): Effect of fatty acids on the rheological behavior of maize starch dispersions during heating. Carbohyd. Polym., 65, 81-92.

RiвotTA, P.D. \& BAiL, A.L. (2007): Thermo-physical assessment of bread during staling. LWT-Food Sci. Technol., $40,879-884$

Shellhammer, T.H., Rumsey, T.R. \& Krochta, J.M. (1997): Viscoelastic properties of edible lipids. J. Food Eng., 33, $305-320$.

StAmpfl, L. \& Nerden, B. (1995): Emulsifiers in bread making. Food Chem., 52, 353-360. 